\title{
IMPLEMENTASI ALGORITMA HYBRID DEPTH-FIRST SEARCH DAN BREADTH-FIRST SEARCH PADA SISTEM REPOSITORY DOKUMEN HASIL KARYA MAHASISWA (STUDI KASUS JURUSAN TEKNOLOGI INFORMASI UNIVERSITAS TADULAKO )
}

\author{
Implementation of Hybrid Algorithm Depth-First Search and Breadth-First \\ Search on Document Repository System of Student Work (A Case Study \\ In Department of Information Technology Tadulako University )
}

\author{
Rizka Ardiansyah \\ Jurusan Teknologi Informasi, Fakultas Teknik Universitas Tadulako; \\ e-mail:rizka@untad.ac.id / ardiansyah.rizka@gmail.com
}

Received 15 / 03 / 2018, Revised 15 / 04 / 2018, Accepted 25 / 04 / 2018

\begin{abstract}
Departement of Information Technology Tadulako University, currently does not have a digital repository system that can accommodate the work of student either in form of paper, research report, and scientific posters at the moment. Various of student works is stored in form of physical archives which is definitely risky to get damaged, lost, difficult to access by other students. The existence of a digital repository system can also be used as a benchmark media to develop student creativity in producing scientific work. Searching mechanism is one of the crucial parts in a repository system. There are several commonly used algorithms such as Depth-First search and Breath-First search. Each algorithm have deficiencies and advantages. Therefore, to optimize the searching mechanism on the proposed digital repository system, the author purpose using the DepthFirst search and Breath-First search hybrid algorithms. The result of this study are the design of a prototipe repository system that able to manage and store student scientific documents archive digitally. This system also has a fast and accurate data search fiture.
\end{abstract}

Keywords - Breath-First search, Depth-First search, digital repository system;

\section{Pendahuluan}

Jurusan Teknologi Informasi Universitas Tadulako adalah salah satu jurusan akademik di Fakultas Teknik Universitas Tadulako. Kegiatan belajar mengajar dalam lingkungan Jurusan Teknologi Informasi sering kali mewajibkan mahasiswa untuk mengumpulkan karya ilmiah dalam bentuk softcopy maupun hardcopy. Namun Saat ini Jurusan Teknologi Informasi belum memiliki sistem repositori digital yang dapat menampung karya ilmiah Mahasiswa baik dalam bentuk jurnal, laporan penelitian (skripsi), makalah, hingga poster ilmiah. Berbagai karya ilmiah Mahasiswa disimpan dalam bentuk arsip fisik yang sangat berisiko rusak, hilang, hingga sulit diakses oleh Mahasiswa lainnya ketika membutuhkan referensi. Hal ini juga merupakan salah satu alasan tingginya tingkat plagiarisme di kalangan mahasiswa Teknik Informatika Untad dalam menyelesaikan tugas penulisan karya ilmiah yang sebagian besar tidak disengaja karena ketidaktahuan bahwa topik tertentu telah diselesaikan sebelumnya. 
Repository adalah konsep untuk mengumpulkan, mengelola, dan menyebarkan seluruh karya karya ilmiah yang dihasilkan oleh civitas perguruan tinggi atau sekolah tinggi [1]. Repositori digital mulai muncul sejak tahun 2003 saat Massachusetts Institute of Technology (MIT) dan Hewlett Packard Corporation bekerjasama mengembangkan DSpace (www.dspace.org) [2]. Repositori ini digunakan di berbagai lembaga termasuk perguruan tinggi untuk menyimpan data-data digital (saving) karya civitas akademika perguruan tinggi tersebut, yang sering dikenal dengan istilah local content information, agar mudah dicari kembali (information retrieval) dan sekaligus sebagai sarana promosi (promotion). Repositori digital pada perguruan tinggi dikenal dengan nama Repositori Insitusi Perguruan Tinggi atau sering disebut Repositori Institusi (RI) saja [3].

Menurut Fatimah [4] Keberadaan sistem repositori digital juga dapat digunakan sebagai media patokan untuk mengembangkan kreativitas Mahasiswa dalam membuat karya ilmiah dan mencegah terjadinya plagiasi karya yang tidak disengaja.

Mekanisme pencarian merupakan bagian penting dalam proses information retrieval sebuah repositori. Sistem repository dokumen digital hasil karya mahasiswa yang dibangun akan menampung berbagai jenis kategori data, mulai dari dokumen laporan karya ilmiah, makalah tugas mahasiswa hingga laporan penelitian mahasiswa(skripsi). Tiap data yang tersimpan memiliki kategori dan atributnya sendiri seperti nama penulis, tahun penulisan, judul serta kategori karya. Aplikasi proses pencarian sederhana melalui querying ke database memiliki indikasi besar menghasilkan data hasil pencarian yang ambigu lintas kategori dokumen. Oleh karena itu diperlukan sebuah mekanisme khusus untuk mengelola proses pencarian agar proses pencarian bisa lebih presisi.

\section{Kajian Pustaka}

Saat ini ada beberapa penelitian yang memiliki keterkaitan konsep permasalah dengan penelitian ini antara lain penelitian yang dilakukan oleh Kristina [5] dan Dodi [6]. Penelitian yang dilakukan oleh Kristina [5] yaitu pengembangan fitur auto-complete pada system pencarian kamus digital istilah biologi yang memanfaatkan algoritma Breath First Search. Pendekatan yang dilakukan adalah dengan memetakan kategori data dalam database kedalam format pohon lalu memanfaatkan BFS untuk melakukan penelusuran. Prinsip pemetaan dan pencarian digambarkan seperti pada gambar 1 dan 2.

\begin{tabular}{|c|c|c|c|}
\hline ID & Istilah kata & $\begin{array}{l}\text { Binomial } \\
\text { Nismeclanere }\end{array}$ & Teriemahan \\
\hline Abl & Abiotik & Abiotk & Benda mati \\
\hline$A b 2$ & Abisal & Abital & $\begin{array}{l}\text { Pambagian bioma air laut dangan } \\
\text { kadalaman daerah }>2000 \text { mater }\end{array}$ \\
\hline $\mathrm{Aml}$ & Amitosis & Amitori: & Pembelahan sel secara langrung. \\
\hline Anl & Angfara & Anatese & $\begin{array}{l}\text { Fase anafase dimulai ketilas } \\
\text { milkrotubula memandek.. }\end{array}$ \\
\hline$A n 2$ & Anaerobik & Anaerobik & $\begin{array}{l}\text { Bakteri yang melakukan } \\
\text { pernafasan tanpa. }\end{array}$ \\
\hline$A n^{3}$ & Anemogami & Anemogami & $\begin{array}{l}\text { Panyerbukan yang diperantara: } \\
\text { olah angin }\end{array}$ \\
\hline $\mathrm{Bal}$ & Bakteri & Bacterium & 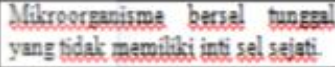 \\
\hline Bil & Bioma & Bioma & $\begin{array}{l}\text { Selkelompok makhluk hidup yang } \\
\text { menempati daerah luss di } \\
\text { permukasn bumi }\end{array}$ \\
\hline
\end{tabular}

Gambar 1. Organisasi Data. 


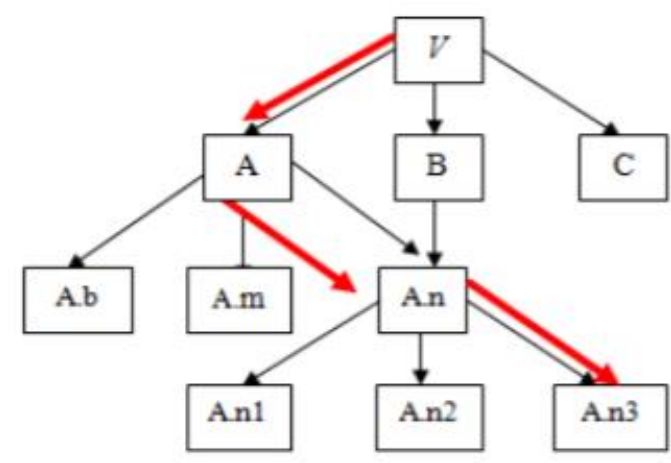

Gambar 2. Penelusuran dengan BFS.

Jika string yang diinputkan untuk dicari terjemahannya adalah anemogami, maka BFS akan melakukan penelusuran mulai dari kategori data terluar (level teratas) hingga ke yang lebih spesifik. Berdasarkan struktur data yang menjadi studi kasus penulis terlihat bahwa BFS mampu berkerja dengan baik pada struktur data pohon yang tidak terlalu lebar. Berdasarkan node yang tersimpan di queue selama proses penelusuran, BFS juga terlihat berkerja dengan sangat efisien karena tidak terlalu butuh alokasi memory yang besar.

Penelitian yang dilakukan oleh Dodi [6] berfokus pada peningkatan jumlah penyebaran informasi, dokumen ataupun artikel yang berdampak pada semakin sulitnya melakukan pencarian data yang relevan diinternet. Penelitian ini membandingkan performa algoritma pencarian Breath First Search dan Depth First Search pada system web crawler yang didukung oleh Naïve Bayes Classifier untuk menilai perbadingan DFS dan BFS tersebut. Hasil yang di dapatkan adalah BFS cenderung memiliki performa yang lebih baik ketika data yang dicari berada tidak begitu jauh dari root, jika tree pencarian sangat dalam dan solusi yang diinginkan tergolong langka pencarian berbasis DFS akan lebih lama dibandingkan BFS. Jika tree pencariannya sangat lebar penggunaan BFS sangat berpotensi menggunakan alokasi memory yang besar.

Berdasarkan studi literatur tersebut maka penulis menyimpulkan bahwa baik DFS maupun BFS memiliki keunggulan dalam lingkungannya masing-masing. Oleh karena itu untuk bisa mendapatkan solusi penggunaan algoritma pencarian yang tepat diperlukan pemahaman terhadap karakteristik data tree yang akan dibentuk.

\section{Hipotesa Penelitian}

Untuk menekan angka plagiarism yang disebabkan oleh ketidaktahuan mahasiswa terhadap topik tertentu yang sudah pernah diselesaikan sebelumnya pada lingkungan Jurusan Teknologi Informasi Universitas Tadulako dan mempermudah pengelolaan terhadap berbagai dokumen akademis mahasiswa agar selain mudah disimpan dan mudah untuk diakses kembali maka system repository digital merupakan solusi untuk masalah tersebut. Sistem repository memungkinkan efisiensi dalam pengalokasian lokasi penyimpanan serta memungkinkan proses pengindeksan data bisa dilakukan dengan lebih baik sehingga memudahkan dalam proses menemukan kembali data yang tersimpan. Dengan pengelolaan berbasis digital repository dokumen yang tersimpan juga akan memiliki resiko minimum terhadap kerusakan dan kehilangan data.

Adanya system repository yang dapat dikelola dengan mudah juga dapat dijadikan sebagai standardisasi karya ilmiah mahasiswa, sehingga kreatifitas mahasiswa dituntut untuk terus 
berkembang melalui eksplorasi berbagai aspek keilmuan yang belum pernah di eksplorasi sebelumnya dalam ruang lingkup Jurusan Teknologi Informasi Universitas Tadulako. Hal ini tentunya membutuhkan peran aktif dari dosen dalam ruang lingkup jurusan untuk turut aktif memonitoring dan mengarahkan mahasiswa dalam proses penelusuran, pengembangan dan dokumentasi karya akademisnya.

Setiap entitas data yang tersimpan pada system digital repository yang dikembangkan memiliki beberapa atribut seperti nama file / judul, kategori, nama penulis, semester penulis dan tahun pembuatan yang melengkapi file data digital yang tersimpan. Hal ini dimaksudkan untuk memudahkan user dalam melakukan proses pencarian dan mengurangi kemungkinan system memberikan nilai balik hasil pencarian yang bias. Untuk mendukung hal tersebut dalam proses pencarian data user diminta menspesifikasikan berbagai atribut pencarian untuk meningkatkan tingkat kepresisian pencarian data.

Pada penelitian ini penulis mengaplikasikan kombinasi algoritma pencarian Breath First Search dan Depth First Search untuk melakukan proses pencarian dan fitur auto completion pada query pencarian. Rancangan konsep implementasinya digambarkan pada gambar 3.

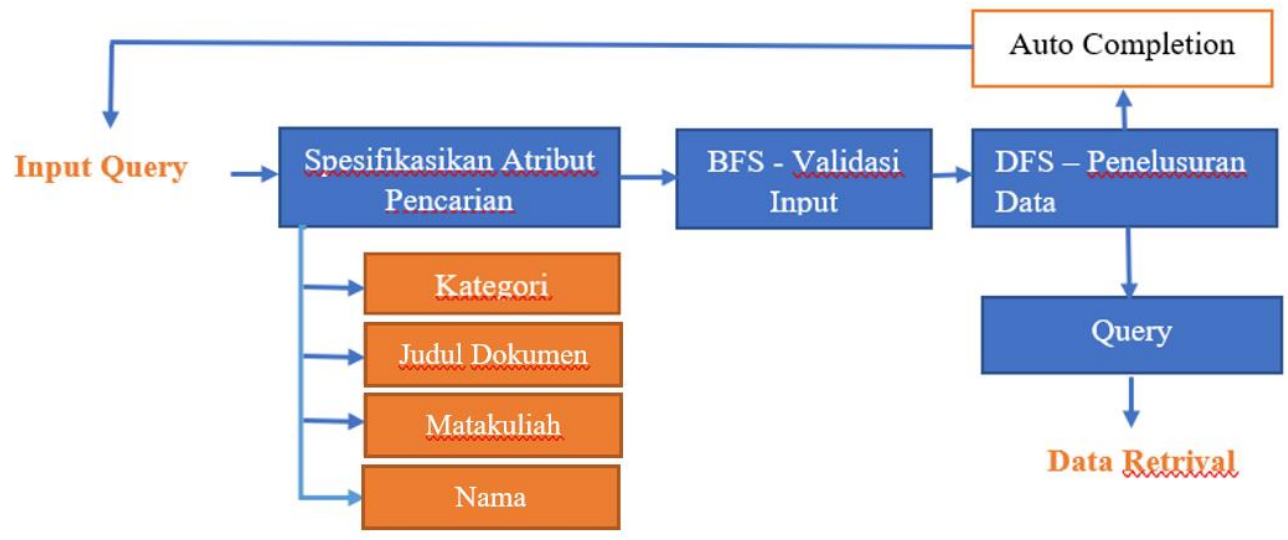

Gambar 3. Implementasi DFS dan BFS dalam proses pencarian.

Berdasarkan gambar 3, setelah user memasukkan input query selanjutnya user menspesifikasikan atribut pencarian. Ada 4 jenis atribut pencarian yaitu Kategori, Nama Penulis, Semester dan Tahun. Keempat atribut ini tidak wajib untuk diisi semua namun tidak boleh sama sekali kosong. Selanjutnya BFS melakukan preprocessing input query beserta atribut pencarian. BFS akan menandai setiap atribut yang terisi dengan 1 dan yang kosong dengan 0. Selanjutnya output dari BFS akan di proses oleh DFS untuk membentuk query ke database sekaligus untuk melakukan penelusuran data untuk fitur auto completion.

Kombinasi algoritma BFS dan DFS ini diarapkan mampu mempermudah proses pencarian dan membantu system agar lebih presisi dalam memproses query untuk mendapatkan hasil yang sesuai dengan espektasi user.

\section{Desain Sistem}

Desain system terbagi dalam beberapa bagian antara lain desain interaksi system, urutan aktifitas system, dan alur proses pencarian data yang terindeks. 


\subsection{Desain Interaksi Sistem}

Desain interaksi system digambarkan dengan menggunakan diagram UML Use Case seperti pada gambar 4.

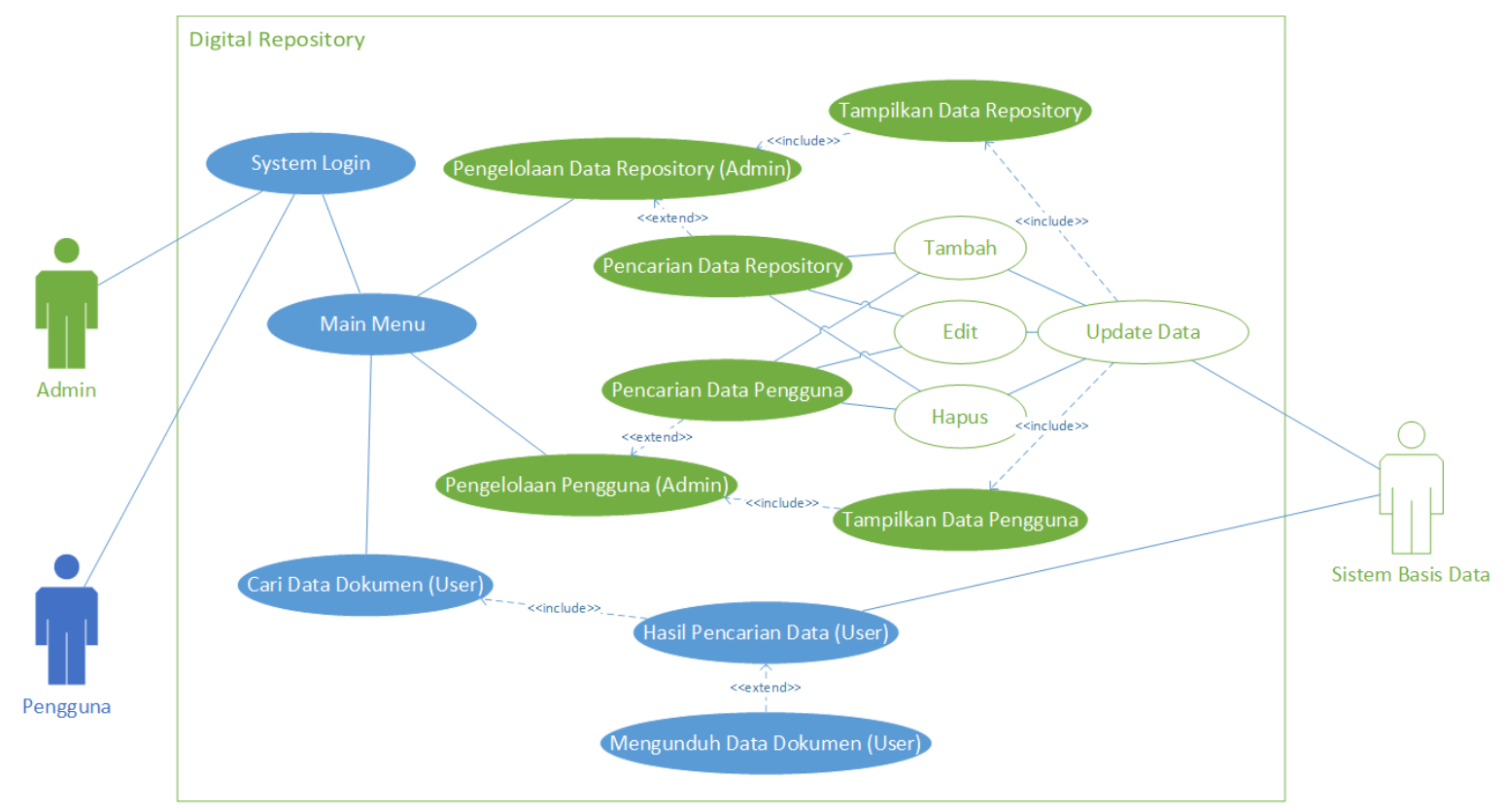

Gambar 4. Diagram Interaksi Sistem.

Sistem digital repository berinteraksi dengan tiga actor yang merupakan entitas diluar system yaitu Admin selaku operator system, Pengguna, dan system basis data selaku system pendukung yang mengelola basis data dari system digital repository. Baik admin maupun pengguna memiliki role dan privilege-nya masing-masing di dalam system. Admin memiliki wewenang untuk melakukan pengelolaan data repository dan pengelolaan data akun pengguna. Pengelolaan melingkupi kemampuan untuk melakukan penambahan entry data baru, pengeditan entri data yang tersimpan dan penghapusan entri data. Untuk memastikan data yang masuk dan tersimpan di dalam digital repository ini merupakan data yang valid, maka hanya admin yang memiliki wewenang untuk menambahkan data di dalam system digital repository.

Akun penguna dapat melakukan pencarian data dokumen digital, melihat data rinci mengenai suatu dokumen yang meliputi waktu pembuatan, nama penulis, hingga kategori dokumen ilmiah, dan melakukan pengunduhan data jika diperlukan. Seluruh proses tersebut hanya dapat dilakukan oleh akun mahasiswa yang terdaftar dan telah diverifikasi melalui proses login sebelumnya.

\subsection{Urutan Aktifitas Sistem}

Urutan aktifitas system digambarkan dengan menggunakan activity diagram. Penggambaran aktifitas system dibagi dalam beberapa activity diagram berbeda antara lain diagram urutan proses pembuatan akun pengguna baru, proses login, proses input data repository, proses pencarian dan pengunduhan arsip data. Diagram urutan proses pembuatan akun baru digambarkan pada gambar 5 . 


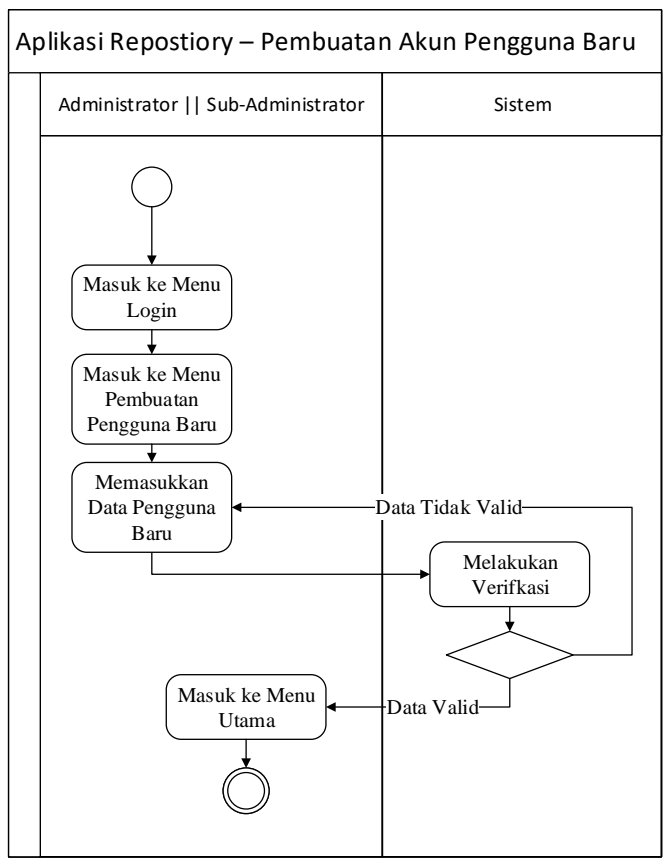

Gambar 5. Diagram Proses Pembuatan Akun Pengguna Baru.

Berdasarkan activity diagram pada gambar 5, apabila seorang administrator atau sub administrator ingin masuk ke system digital repository maka telebih dahulu harus melalui menu login. Proses autentikasi akun pengguna diverifikasi pada halaman login untuk memastikan hanya akun yang terdaftar yang berhak mengakses system. Selanjutnya masuk ke menu pembuatan pengguna baru untuk mendaftarkan akun pengguna baru beserta username dan passwordnya. Akun pengguna baru harus memiliki identitas utama berupa kartu tanda mahasiswa yang aktif. Setelah data dimasukkan sistem akan melakukan verifikasi. Apabila datanya valid maka akan masuk ke menu utama. Namun apabila datanya tidak valid maka akan kembali ke bagian pengisian data pengguna baru.

Diagram urutan proses login digambarkan seperti pada gambar 6. Proses login ini bertujuan untuk memastikan hanya pengguna yang memiliki hak akses yang dapat mengakses system, yaitu administrator yang di tunjuk secara resmi oleh pihak jurusan dan mahasiswa aktif Jurusan Teknologi Informasi Universitas Tadulako. Berdasarkan activity diagram pada gambar 6 apabila administrator, sub administrator, atau pengguna ingin masuk ke aplikasi ini maka terlebih dahulu masuk ke menu login. Selanjutnya masukkan id dan password yang sebelumnya telah terdaftar di sistem. Setelah data dimasukkan sistem akan melakukan verifikasi data yang diinputkan dengan data yang tersimpan di database. Apabila datanya valid maka akan masuk ke menu utama sesuai dengan status masingmasing user. Namun apabila datanya tidak valid maka akan kembali ke bagian pengisian data login. 


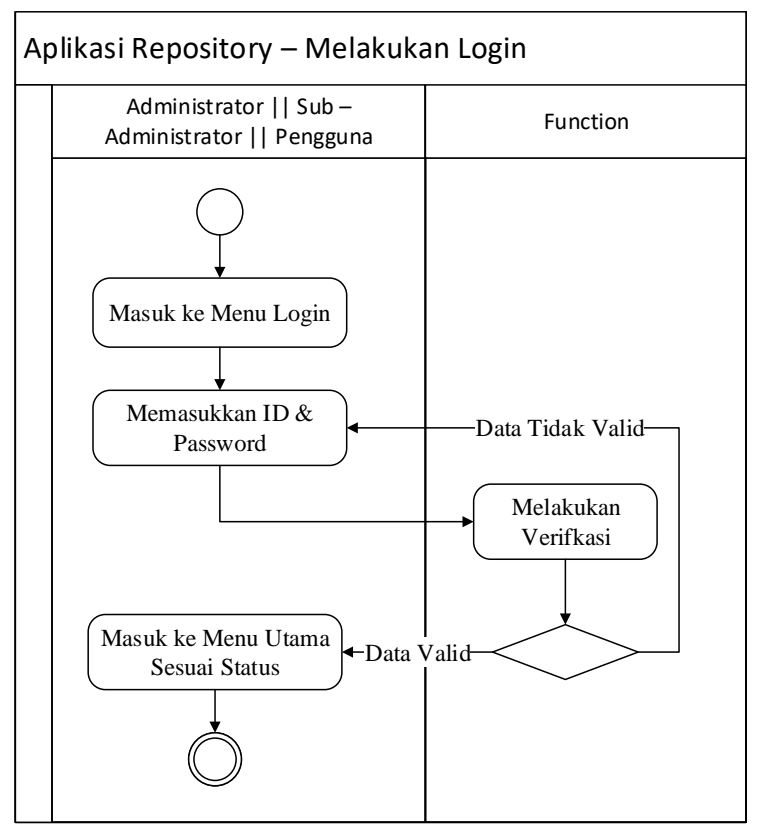

Gambar 6. Diagram Proses Login Sistem.

Diagram urutan proses pengunggahan data berupa dokumen ilmiah mahasiswa dalam bentuk soft file digambarkan seperti pada gambar 7. Proses pengunggahan data hanya dapat dilakukan oleh admin atau sub-admin system yang ditunjuk dan memiliki hak akses. Hal ini demi memastikan data yang tersimpan sesuai dengan standart kelayakan dokumen yang dapat diarsipkan pada system digital repository.

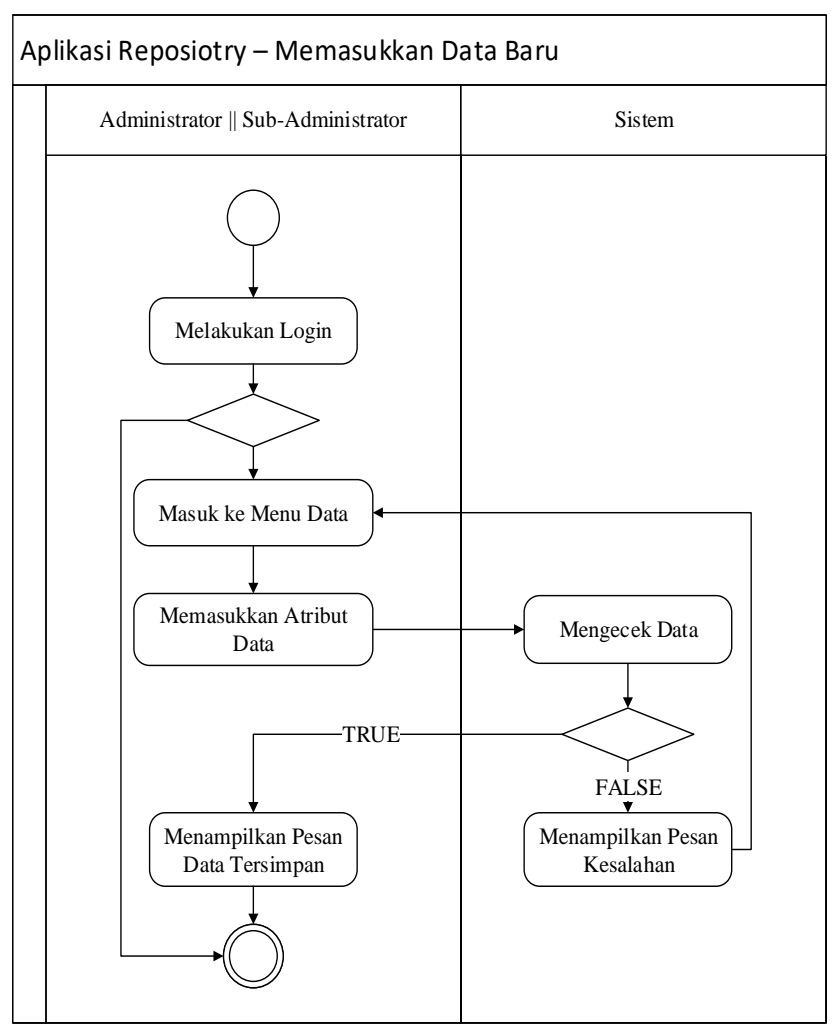

Gambar 7. Diagram Proses Pengunggahan Data Dokumen Ilmiah Mahasiswa. 
Berdasarkan activity diagram pada gambar 7, apabila administrator atau sub administrator ingin masuk ke aplikasi ini maka telebih dahulu masuk ke menu login. Setelah login maka akan masuk ke menu data. Setelah itu memasukkan atribut data. Selanjutnya sistem akan mengecek data tersebut apakah bernilai true atau false. Jika bernilai true maka akan menampilkan pesan data tersimpan. Jika bernilai false maka sistem akan menampilkan pesan kesalahan dan akan kembali ke bagian menu data.

Diagram urutan proses pencarian dan pengunduhan data berupa dokumen ilmiah mahasiswa dalam bentuk soft file digambarkan seperti pada gambar 8 .

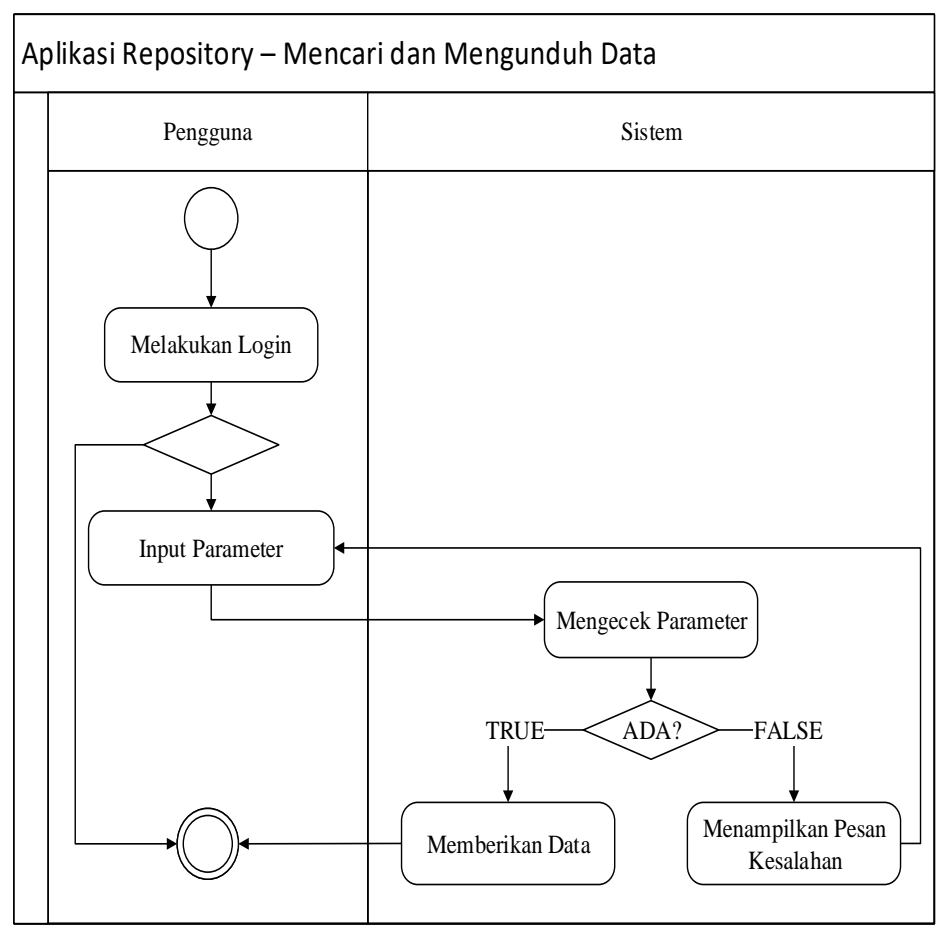

Gambar 8. Diagram Proses Pencarian dan Pengunduhan Data Dokumen Ilmiah Mahasiswa.

Berdasarkan activity diagram pada gambar 8 , sebelum pengguna dapat mengakses halaman pencarian data pengguna harus melakukan login terlebih dahulu. Setelah login pengguna akan diantarkan pada halaman pencarian data repository. Pada halaman pencarian data pengguna dapat menginput parameter pencarian yang akan diproses lebih lanjut oleh sistem. Selanjutnya sistem akan mengecek apakah parameter tersebut bernilai true atau false (terisi atau tidak). Jika bernilai true maka sistem memberikan data. Jika bernilai false maka sistem akan menampilkan pesan kesalahan dan akan kembali ke bagian input parameter. Pada system yang dibangun pengguna dapat hanya mengisi satu saja parameter pencarian entah itu parameter berupa judul, kategori dokumen ataupun yang lainnya. Jika parameter pencarian banyak yang kosong hal ini akan mempengaruhi akurasi data pencarian sehingga menjadi kurang spesifik. Opsi pengunduhan dimungkinkan setelah system menampilkan hasil pencarian data. 


\subsection{Perancangan Proses Pencarian}

Proses pencarian pada sistem digital repository yang dibangun berbasis algoritma hybrid BreathFirst Search dan Depth-First Search. Rancangan algoritma proses pencarian data digambarkan seperti pada gambar 9 .

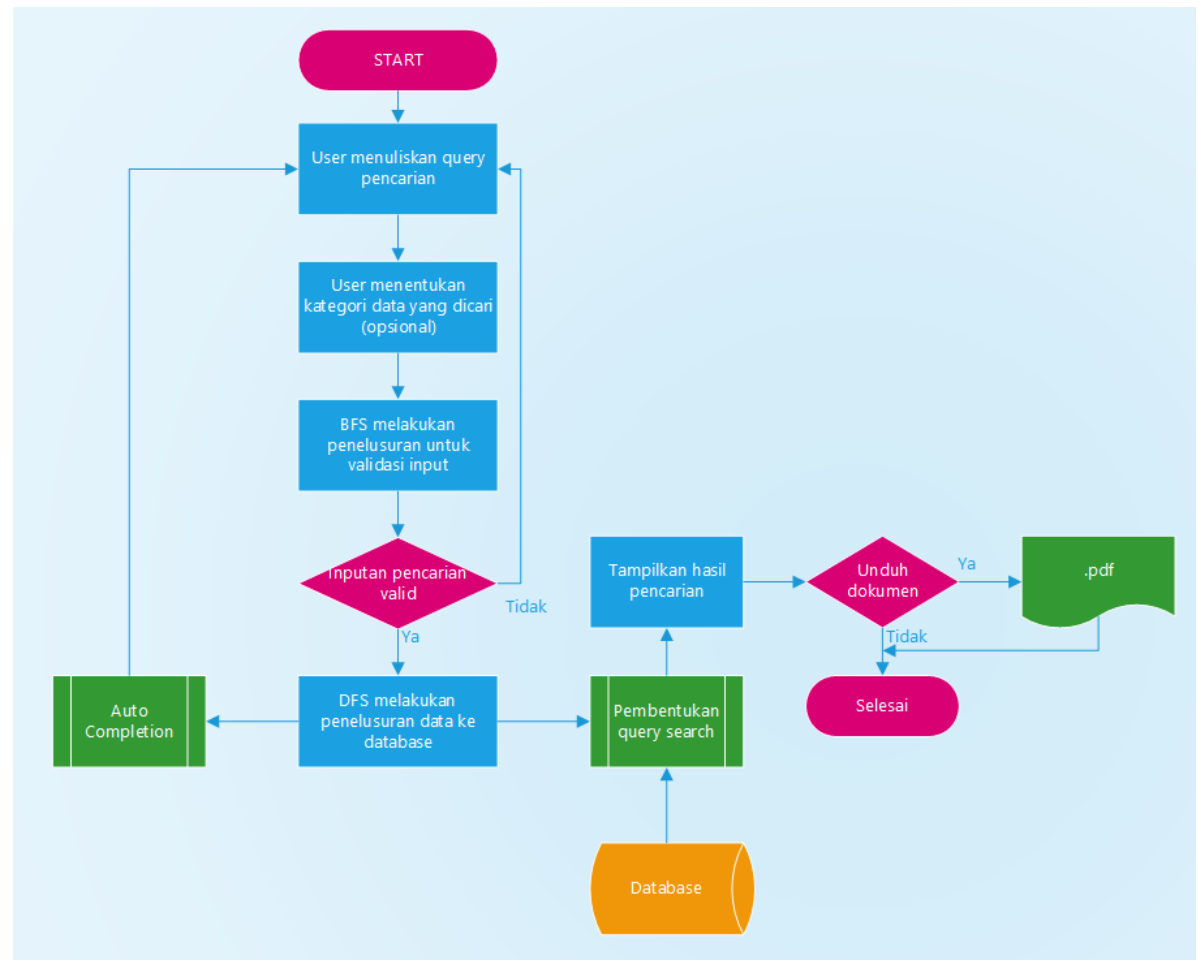

Gambar 9. Flowchart Proses Pencarian Data.

Berdasarkan flowcart pada gambar 9, proses pencarian data dilakukan berdasarkan query yang diinputkan oleh user pada kolom inputan pencarian dan berdasarkan informasi pelengkap yang ditentukan oleh user. Informasi pelengkap boleh diisi atau pun tidak oleh user. Jenis informasi pelengkap antara lain kategori dokumen, matakuliah asal dokumen (jika dokumen merupakan bentuk penugasan dari matakuliah tertentu), dan nama pemilik dokumen. Algoritma BFS akan melakukan penelusuran terhadap input lalu menentukan validitas input. Jika user sama sekali tidak mengisikan parameter pencarian maka nilai balik dari pemrosesan BFS adalah 0000 yang berarti tidak ada parameter yang bisa di proses, maka input tidak valid. Selanjutnya output dari BFS akan di proses oleh algoritma DFS untuk melakukan penelusuran data di database. Hasil penelusuran data tree oleh algoritma DFS membantu user dalam menuliskan query pencarian dokumen yang mendukung fitur auto completion. Hasil penelusuran DFS juga merupakan parameter utama untuk melakukan querying ke database. Setelah dilakukan querying ke database selanjutnya data yang didapat diurutkan berdasarkan relevansinya pada kolom hasil pencarian. Pengguna dapat memilih dokumen yang dimaksud lalu akan tampil opsi untuk mengunduh dokumen yang dipilih.

\section{Hasil dan Pembahasan}

Perangkat lunak dikembangkan berbasis .net dengan IDE Visual Studio Community 2017 sebagai media pembuatan dan perancangan sistem, menggunakan MySql Server sebagai provider database, 
untuk konektornya sendiri menggunakan konektor mySQL Server standart DotNet yang yang telah disediakan oleh library .net.

Pengujian sistem terbagi menjadi dua jenis, yaitu pengujian fungsionalitas sistem secara keseluruhan dan pengujian sistem proses pencarian data pada sistem repository yang dibangun. Pengujian fungsi sistem dilakukan dengan metode blackbox untuk mengetahui apakah fungsi-fungsi yang terdapat dalam sistem berjalan dengan baik atau tidak. Hasil dari pengujian fungsionalitas sistem adalah setiap langkah pengujian dapat diselesaikan sesuai dengan target capaian yang telah ditetapkan.

Hasil pengujian dari sistem pencarian data pada aplikasi repository dapat dilihat pada gambar 10 dan 11 dibawah ini.

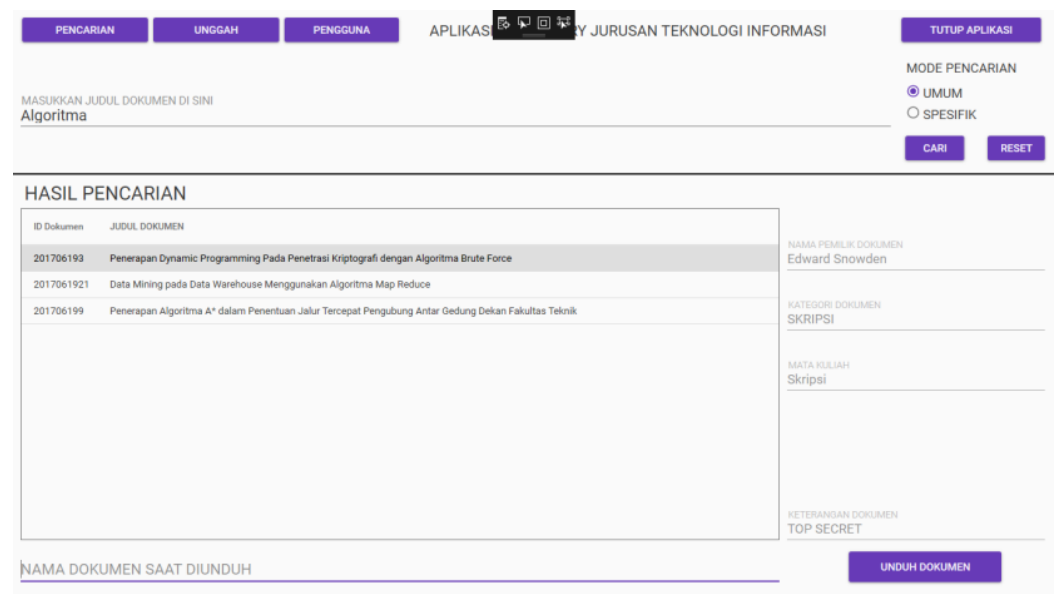

Gambar 10. Pengujian Sistem Pencarian Umum.

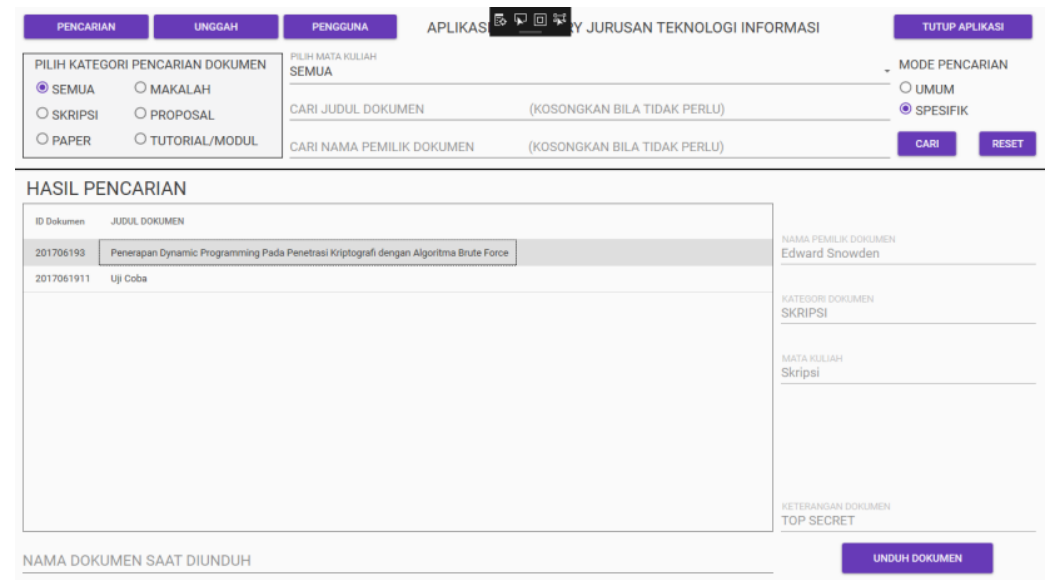

Gambar 11. Pengujian Sistem Pencarian Spesifik.

Sistem pencarian data yang dibangun pada sistem digital repository terbagi dalam dua jenis yaitu pencarian sederhana seperti yang digambarkan pada gambar 10 dan pencarian spesifik seperti yang digambarkan pada gambar 11. Pencarian umum tidak melibatkan algoritma DFS maupun BFS, input 
user langsung di proses kedalam sql query untuk selanjutnya langsung dikirim ke database. Pencarian umum hanya melibatkan satu kategori record saja baik itu judul karya, nama penulis atau kategori dokumen. Sehingga umumnya pengembalian data yang didapatkan akan lebih banyak dan kurang presisi. Pencarian khusus adalah pencarian yang melibatkan beberapa atribut data. Pencarian ini melibatkan algoritma DFS dan BFS. Terdapat beberapa tahapan yang dilakukan dalam sistem repositori menggunakan algoritma hybrid, yaitu :

1. Pemilihan Mode

Pada aplikasi ini pengguna harus menggunakan mode pencarian spesifik agar dapat mengerucutkan hasil pencarian dengan algoritma hibrida, ketika masuk ke menu pencarian spesifik akan ada beberapa parameter yang akan menjadi spesifikasi dalam pencarian.

\section{Pemilihan Parameter}

Setelah masuk ke menu pencarian spesifik pengguna harus memilih beberapa parameter sebagai penentu query yang akan dimasukkan ke dalam eksekusi sistem.

3. Eksekusi Parameter

Parameter yang dieksekusi akan menentukan komando yang akan dimasukkan ke basis data dan hasil eksekusinya akan dikembalikan ke aplikasi.

Berdasarkan pengujian yang dilakukan, mode pencarian spesifik dapat memberikan nilai balik berupa data yang lebih spesifik kepada pengguna.

\section{Kesimpulan}

1. Sistem digital repository yang dibangun dapat mengefisiensinkan proses pengarsipan data dokumen ilmiah mahasiswa. Proses submission, monitoring dan data retrival dapat dilakukan dengan lebih mudah. Hanya saja karena sistem yang dibangun berbasis aplikasi desktop sehingga memiliki keterbatasan dalam jangkauan akses.

2. Berdasarkan pengujian dan analisis mekanisme pencarian data sistem repositori menggunakan algoritma hybrid hasil penggabungan BFS dan DFS, dapat disimpulkan bahwa dengan menerapkan algoritma pencarian hybrid proses pencarian data dengan multi-atribut bisa lebih cepat dan spesifik karena sebelum melakukan pencarian mendalam ke dalam basis data program akan terlebih dahulu menyesuaikan dengan parameter yang dimasukkan untuk selanjutnya menentukan query yang akan dieksekusi.

\section{DAFTAR REFERENSI}

[1] Hasan, Thamrin, 2012 UR Digital Repository Suatu Perjuangan Informasi. UPT Perpustakaan Universitas Riau.

[2] C. Lynch, 2003 Institutional Repositories: Essential Infrastructure For Scholarship In The Digital Age, portal: Libraries and the Academy, vol. 3, no. 2, pp. 327-336.

[3] Antonius Rachmat, 2014 Analisis Rancanga Bangun Sistem Repository Institusi Berbasis MetaData Dublin Core di UKDW Jogja, UltimaInfoSys :Jurnal Ilmu Sistem Informasi, Vol.5, No.2. 
[4] Fatimah Noor, dkk., 2017 Perancangan system Repository Skripsi Berbasis WEB (Studi Kasus : STIMIK Provinsi Semarang), Jurnal Teknologi Informasi dan Komunikasi : PROVISI, Vol.6 No.1.

[5] Kristina, Wardani, 2015 Implementasi Algoritma Breath First Search dalam Arti Kata Bahasa Ilmiah Biologi, Universitas Nusantara PGRI Kediri, Artikel Skripsi.

[6] Doddy Teguh Yuwono, dkk., 2016 Perbandingan Algoritma Breath First Search dan Depth First Search Sebagai Focuser Crawler, Prosiding Annual Research Seminar 2016, Universitas Sriwijaya, ISBN: 979-587-626-0. 